\title{
The paradoxical effects of analgesics and the development of chronic migraine
}

\author{
Marcelo E. Bigal
}

\begin{abstract}
In a subgroup of individuals episodic migraine evolves into a stage where individuals have headaches on more days than not. Among the risk factors for chronification, excessive use of analgesic medications figure prominently and reviewing this topic is the scope of this article. The issue of causality is discussed and evidence suggesting that specific medications, at critical doses, are risk factors for chronic migraine (CM) is reviewed. The concept of critical dose of exposure for different classes is presented and biological plausibility and putative mechanisms are reviewed.
\end{abstract}

Key words: migraine, chronic migraine, medication overuse headache, migraine progression.

\section{Migrânea crônica e os efeitos paradoxais dos analgésicos}

\section{RESUMO}

Fração não desprezível de pacientes com migrânea episodica evolve para um estágio em que cefaléias acontecem na maior parte dos dias. Dentre os fatores de risco para esse processo de cronificação, o uso excessivo de analgésicos tem importância particular e é o tema desse artigo. A causalidade da associação é discutida, assim como a especificidade da associação. Evidência sugerindo que doses críticas de exposição podem ser inferidas também é revisada, assim como a plausibilidade da associação e mecanismos da mesma. Palavras-chave: migrânea, migrânea crônica, abuso de analgésicos.

The natural history and the prognosis of migraine have not been well described, but evidence and clinical observation suggest 4 patterns of evolution ${ }^{1}$. In some, migraine sufferers clinically remit, becoming symptom-free over prolonged periods of time (Clinical Remission). In others, migraine gets less typical over time, resembling probable migraine or even tensiontype headache, rather than full-blown migraine (Partial Clinical Remission). In many, migraine has an unremitting course (Clinical Persistence). Finally, in some, migraine progresses (Progression) ${ }^{1}$.

The progression of migraine from an episodic into a chronic form (CM) has several characteristics. First, it does not happen abruptly. Indeed, transfor- mation is often gradual, where individuals move from a stage where they have low frequency episodic headaches into a high frequency stage, and eventually into $\mathrm{CM}^{2-5}$. Second, transformation is neither inexorable, nor irreversible. Spontaneous or induced (by health interventions) remissions are possible and common ${ }^{2}$. Third, transformation happens in some but not most individuals; nonetheless, the final end of transformation, CM, is relatively frequent ${ }^{1,2}$. Population studies show that around 3\% of the individuals with episodic migraine transform into $\mathrm{CM}$ in a typical year ${ }^{6}$.

Because migraine does worsen in a sizeable subgroup of sufferers, but not in most, identifying factors that predict the 
change from episodic into $\mathrm{CM}$ is of extreme interest and should be seen as a priority in headache research ${ }^{1}$. These risk factors provide insights into the mechanisms of disease as well as a foundation for interventions intended to modifying the course of illness.

Among the risk factors for CM, excessive use of analgesic medications figure prominently ${ }^{7-10}$. Excessive use of analgesics is a modifiable risk factor for migraine progression, since guidelines may provide clear recommendation about proper use. Nonetheless, the issue is of relevance. Taking opioids as a prototype, their potency and use has expanded over the past few decades ${ }^{11}$. At a given time, 2.2\% percent of U.S. adults (over 5 million persons) report regular use of prescribed opioids ${ }^{12}$. Use of prescription opioids for musculoskeletal pain patients in the U.S. has doubled in recent years (from $8 \%$ to $16 \%)^{13}$.

Accordingly, doctors treating migraine face a serious dilemma. Although analgesics are effective and must play an important role in the treatment of migraine ${ }^{14}$, if excessively used, they may indeed exacerbate migraine, justifying public health interventions that include recommendations on the judicious use of symptomatic medications together with early use of preventatives ${ }^{15}$.

A second dilemma faced by doctors regards addressing causality. Doctors often see patients that come with daily headaches and daily use of medications. The immediate doubt that arises as to whether the daily use of analgesics is indeed the cause of the chronic daily headaches $(\mathrm{CDH})$, or if the use of analgesics happened in an individual that was developing $\mathrm{CDH}$ s because of another reason ${ }^{16,17}$. Finally, for many years, the evidence linking excessive medication use and paradoxical increase of pain has been questionable or controversial. Accordingly, the aim of this paper is to review the evidence linking medication overuse to CM. Since some studies did not study CM as currently defined, the terms $\mathrm{CM}$ and $\mathrm{CDH}$ are used interchangeably. The issue of causality is discussed and evidence suggesting that specific medications, at critical doses, are risk factors for chronic migraine is presented. The issue of biological plausibility and putative mechanisms to explain the relationship is also discussed.

\section{A brief discussion on classification}

Discussing the classification of the frequent headache syndromes is beyond the scope of this review and the readers are referred to the following papers: ${ }^{18-20}$. In brief, chronic daily headaches refer to primary headaches that occur for $\geq 4$ hours a day on $\geq 15$ days a month over $>3$ months ${ }^{21}$.

Primary CDHs have been traditionally divided following the criteria proposed by The Silberstein and Lipton in transformed migraine (TM), chronic tension- type headache (CTTH), new daily persistent headache (NDPH) and hemicrania continua (HC), and sub-classify each of these into subtypes "with medication overuse" or "without medication overuse" ${ }^{\text {"21 }}$. Of these, the First Edition of the International Classification of Headache Disorders (ICDH- 1$)^{22}$ included only CTTH while the second edition (ICHD-2 $)^{23}$ has detailed diagnostic criteria for all four types of primary $\mathrm{CDH}$ of long duration. The term chronic migraine was introduced in place of TM, and has a very different definition, as discussed below. Though vastly improved, recent studies show that the ICHD-2 remains cumbersome for the classification of adults with $\mathrm{CDH}^{24}$. More recently, the ICHD-2 has considering revising the $\mathrm{CM}$ criteria, moving it to the appendix.

\section{Evidence linking excessive use of medication and CM}

Evidence from clinic based studies - Several clinicbased studies have assessed the relationship between symptomatic medication overuse (SMO) and migraine progression (Table 1). These studies are often limited by the selection bias that leads people to seek care in the research setting under investigation, but of attention is the uniformity of the findings. Furthermore, a series of these studies addressed the importance of analgesic use when used for non-headache causes in individuals with migraine.

The best evidence that medications are a risk factor for new onset chronic daily headache comes from a longitudinal headache clinic-based study conducted in Essen, Germany. Katsavara and associates showed that among persons with episodic migraine, use of acute medication was associated with a frequency of use dependent increase in the new onset daily headache over the course of a year. In multivariate models, both headache frequency and days of medication overuse were independent and potent predictors for the development of new onset CDH. Among the medications overused, opioid was the strongest risk factor ${ }^{25}$.

As mentioned, a number of clinic-based studies examined the influence of medication use for reasons other than headache in persons with and without migraine. One study looked for $\mathrm{CDH}$ in 28 patients who underwent total colectomy for ulcerative colitis, treated with daily opioids to control bowel movements, not for pain. Two patients had CDH starting after surgery. Both used daily opiates following surgery and both had a prior history of migraine. The other six patients who used opiates daily did not have a history of migraine, and did not develop $\mathrm{CDH}$. The authors concluded that opioid use may be a risk factor for $\mathrm{CDH}$ just in those with pre-existing migraine ${ }^{26}$.

In a rheumatology clinic, 103 of 110 patients were 
Table 1. Summary of clinic based studies.

\begin{tabular}{|c|c|c|c|c|}
\hline $\begin{array}{l}\text { Reference } \\
\text { number }\end{array}$ & Sample/setting & Methods & Sample & Results \\
\hline 26 & $\begin{array}{l}\text { Women with total col- } \\
\text { ectomy using opiates } \\
\text { for bowel movement } \\
\text { control. }\end{array}$ & Questionnaire interview. & $\begin{array}{l}\text { - } 69 \text { surveyed. } \\
\text { - } 32 \text { returned questionnaires (46\%). } \\
\text { - } 28 \text { included in analyses (daily } \\
\text { acetaminophen users excluded). } \\
\text { - } 18 \text { using opiates. } \\
\text { - } 2 \text { with CDH (6.2\% of responders). }\end{array}$ & $\begin{array}{l}\text { - Opiate use was not different in } \\
\text { migraine vs not. } \\
\text { - The } 2 \text { individuals with } C D H \\
\text { were overusing opiate and had } \\
\text { migraine in the past. }\end{array}$ \\
\hline 27 & $\begin{array}{l}\text { Consecutive attendees } \\
\text { (both genders) at a } \\
\text { rheumatology-moni- } \\
\text { toring. }\end{array}$ & $\begin{array}{l}\text { Direct interview by neu- } \\
\text { rologist. }\end{array}$ & $\begin{array}{l}\text { - } 111 \text { interviewed (80\% women). } \\
\text { - } 103 \text { using frequent analgesics. } \\
\text { - } 8 \text { with CDH (7.2\%). }\end{array}$ & $\begin{array}{l}\text { - All individuals with CDH had a } \\
\text { prior history of migraine vs. } 40 \% \\
\text { in those without CDH. } \\
\text { - } 75 \% \text { of the individuals CDH were } \\
\text { using opiates vs. } 24 \% \text { without } \\
\text { CDH. }\end{array}$ \\
\hline 25 & $\begin{array}{l}\text { Individuals with epi- } \\
\text { sodic migraine consec- } \\
\text { utively seen in a head- } \\
\text { ache clinic. }\end{array}$ & $\begin{array}{l}\text { Chart review of structured } \\
\text { questionnaires and head- } \\
\text { ache-specialist diagnosis. }\end{array}$ & - 532 patients with migraine. & - Incidence of CDH was $14 \%$. \\
\hline 28 & $\begin{array}{l}\text { Individuals with cluster } \\
\text { headache seen in a } \\
\text { headache center. }\end{array}$ & Charts review. & $\begin{array}{l}\text { - } 17 \text { individuals with cluster head- } \\
\text { ache who also developed CDH over } \\
\text { their treatment. }\end{array}$ & $\begin{array}{l}\text { - } 15(88.2 \%) \text { had a prior history of } \\
\text { migraine. }\end{array}$ \\
\hline 29 & $\begin{array}{l}\text { All patients attending } \\
\text { a rheumatologic clinic } \\
\text { over a } 4 \text { week period. }\end{array}$ & Questionnaire interview. & $\begin{array}{l}\text { - } 114 \text { participants (participation } \\
\text { rate not reported. } \\
\text { - } 14(12.2 \%) \text { had } C D H \text {. } \\
\text { - } 80(70.1 \%) \text { patients used analge- } \\
\text { sics more than } 15 \text { days per month. }\end{array}$ & $\begin{array}{l}\text { - } 80 \text { (70.1\%) patients used analge- } \\
\text { sics more than } 15 \text { days per month. } \\
\text { - } 13 / 14(92.8 \%) \text { of CDH sufferers } \\
\text { had SMO. } \\
\text { - Rates of use of specific medica- } \\
\text { tions comparing CDH vs not are } \\
\text { not presented. }\end{array}$ \\
\hline
\end{tabular}

using one or more analgesics regularly for their arthritis $^{27}$. Of this group, 8 (7.6\%) had CDH, each of whom reported a history of migraine. Five of those with regular use of analgesics had been taking an opiate-based preparation. Two had been on a combination of acetaminophen and a nonsteroidal anti-inflammatory drug. The minimum number of tablets per week was 7 , and the mean was 48 (range, 7 to 87 ).

More recently, in a retrospective series of $17 \mathrm{pa}$ tients (13 men, 4 women) with cluster headache who also developed $\mathrm{CDH}$, an association with overuse of a wide range of monotherapies (for cluster headaches) was found. They included varying combinations of simple analgesics $(n=9)$, caffeine $(n=1)$, opioids $(n=10)$, ergotamine $(\mathrm{n}=3)$, and triptans $(\mathrm{n}=14)$. The common denominator in 15 patients was a personal or family history, or both, of migraine ${ }^{28}$.

Finally, a recent study assessed the development of $\mathrm{CDH}$ in individuals with chronic use of analgesics due to rheumatologic problems. Among 114 rheumatology patients, $12 \%$ fulfilled criteria for $\mathrm{CDH}$. Comparisons of medication intake among those who developed $\mathrm{CDH}$ vs not were not reported ${ }^{29}$.

Interpretation of the clinic-based studies - Taken together, these studies suggest that use of acute med- ications, particularly opioids, is associated with an increased risk of $\mathrm{CDH}$ in persons with migraine. There is little evidence that these medications are associated with $\mathrm{CDH}$ in persons free of a personal and family history of migraine. These data suggest a diathesis stress model for $\mathrm{CDH}$._When the diathesis, migraine, is combined with the stress, pattern of medication use, $\mathrm{CDH}$ may develop ${ }^{2}$.

\section{Evidence from population-based studies}

Population-based studies reduce the problem of selection bias which limits the clinic-based studies. Herein we consider cross-sectional, case-control and cohort designs. Though each design has limitations, findings across these designs are robust and complementary.

Cross-sectional data - Since individuals with chronic migraine have more days of headache per month than individuals with episodic migraine, analgesic consumption is predictably higher in those with CM. Patterns of disproportionate use may be informative. In 2005, the American Migraine Prevalence and Prevention (AMPP) Study, sent mailed questionnaires to 24,000 severe headache sufferers drawn from a much larger population survey ${ }^{30}$. As a part of the survey, subjects were asked to report the specific medications currently used for their most severe headaches, dose, and number of 
days per month using medication. Several differences were seen between the acute treatment of CM and episodic migraine in the population. Barbiturates were more commonly used by those with CM [crude odds ratio $(\mathrm{OR})=2.46,95 \%$ confidence interval $(\mathrm{CI})=1.9-3.2)]$, as were opioids (OR=2.1, 95\% CI 1.9-2.6). Triptan use was non significantly increased in $\mathrm{CM}(\mathrm{OR}=1.22,95 \%$ CI $0.98,1.51)$. Non-steroidal anti-inflammatory drugs (NSAIDs) and combination of over-the-counter medications (OTCs) were less frequently used by those with $\mathrm{CM}$ than migraineurs ${ }^{31}$.

This study suggested an association between specific classes of medication (barbiturates and opioids) and CM. Causal inferences are weak because patterns of medication may be a consequence of rather than a risk factor for CM. At cross-section we can not determine the temporal sequence.

Case-control studies - Case-control studies take temporal sequence into account by focusing on exposures prior to the onset of the condition of interest. As a part of the Frequent Headache Epidemiology Study ${ }^{32}$, individuals with $\mathrm{CDH}$ and controls (episodic or no headaches) were identified in the population, and estimates of medication consumption (for headache and other forms of pain) were obtained ${ }^{33}$.

$\mathrm{CDH}$ individuals were significantly more likely to be current users of compounds containing caffeine [27.1\% vs. $16.1 \%$; odds ratio $(\mathrm{OR})=1.6,95 \%$ confidence interval $(\mathrm{CI})=1.0-2.7)]$, and were twice more likely to be using compounds containing opiates $(13.3 \%$ vs. $6.1 \%$; $\mathrm{OR}=2.0,95 \% \mathrm{CI}=0.9-4.5)$. For barbiturates, they were also twice more likely [to what - to have $\mathrm{CDH}$, or use other drugs??], but, as for opiates, significance was not achieved likely due to sample size limitations. Aspirin was less common in $\mathrm{CDH}$ in crude analyses but not in adjusted. Naproxen was non-significantly increased in individuals with $\mathrm{CDH}(\mathrm{OR}=1.5,95 \% \mathrm{CI}=0.7-2.8)$.

When medications for headache and pain were pooled together, in crude comparisons, $\mathrm{CDH}$ was associated with current use of OTC/caffeine combination products, triptans, butalbital compounds, opioids compounds, and 'other' prescription pain medications. Use of aspirin was protective. However, after adjustment, only aspirin remained protective to $\mathrm{CDH}$, while opioid compounds remained associated with $\mathrm{CDH}$.

Longitudinal studies - Two large scale longitudinal population studies have assessed the relationship between medications and $\mathrm{CM}$ or $\mathrm{CDH}$. As a part of the Head-HUNT study, a large, longitudinal, population-based study assessing the relationship between acute medication overuse and $\mathrm{CDH}$, as well as to other chronic pain syndromes, analgesic use was assessed in 32,067 adults in 1984-1985 and again 11 years later ${ }^{34}$.
Those who used analgesics daily or weekly at baseline had a higher risk ratio (RR) for chronic migraine (13.3), chronic non-migrainous headache $(R R=6.2)$ and chronic neck pain $(R R=2.4)$ at follow-up. The authors concluded that overuse of analgesics predicted the development of overall $\mathrm{CDH}$ in the population.

In this study, information on medication overuse was collected at baseline and at follow-up. However, because the authors did not collect information on the headache status at baseline, they could not exclude the possibility that frequent analgesic use was simply a marker for frequent headache. Nor could they determine if SMO was associated with $\mathrm{CDH}$ just in those with migraine at baseline, or in everyone.

Using longitudinal data from the American Migraine Prevalence and Preventions study, the probability of transition from episodic migraine (EM) in 2005 to CM in 2006 was modeled as a function of acute medication use in $2005^{35}$ using acetaminophen as the reference, after adjusting for covariates. Below we discuss the results for the fully adjusted models highlighting various aspects of the analysis.

[1] Use of opioids or barbiturates was associated with an increased risk of new onset CM: Table 2 summarizes the risk of new onset CM by medication class. In unadjusted analyses, compounds containing barbiturates and opiates were associated with a two-fold increased risk of CM in 2006 vs. maintaining an episodic migraine status (Barbiturates OR=2.06, 95\% CI=1.3-3.1; opiates $\mathrm{OR}=1.98,95 \% \mathrm{CI}=1.4-2.8)$. The other classes of medications were not associated with a significant risk of new onset CM overall. (Table 2). In the adjusted analysis the effects or barbiturates and opioids are attenuated somewhat but remain statistically significant (Table 2).

[2] The influence of medication varies according to the baseline headache frequency as well as drug class: To disentangle the influence of headache frequency and medication use, we adjusted for the number of headache days per month among other factors, using acetaminophen as a reference group. In these adjusted analyses, those using barbiturates ( $\mathrm{OR}=1.73,95 \% \mathrm{CI}=1.1-2.7)$ or opiates $(\mathrm{OR}=1.4,95 \% \mathrm{CI}=1.1-2.1)$ were at increased risk of incident $\mathrm{CM}$ compared to those using acetaminophen. Those using triptans $(\mathrm{OR}=1.05,95 \% \mathrm{CI}=0.8,1.6)$ or NSAIDs (OR=0.97, 95\% CI=0.7-1.34) were not. Results were similar for women and men, except that the risk of incident $\mathrm{CM}$ associated with use of opioids was higher in men $(\mathrm{OR}=2.76)$ compared to women $(\mathrm{OR}=1.28)$.

[3] Baseline headache frequency and gender alter the risk of new onset CM in a manner that depends upon medication class and dose: The influence of baseline headache frequency was evident for all classes of medication. For a specific exposure (days of use), higher 
Table 2. Association of medication use for migraine in 2005 as a predictor of headache status in 2006 stratified by gender. After ${ }^{37}$ - is this referring to after age 30? Wasn't clear what after (30) means.

\begin{tabular}{|c|c|c|c|c|c|}
\hline & $\begin{array}{c}\text { Unadjusted } \\
\text { Women } \\
\text { OR }(95 \% \mathrm{Cl})\end{array}$ & $\begin{array}{c}\text { Adjusted } \\
\text { Women } \\
\text { OR }(95 \% \mathrm{Cl})\end{array}$ & $\begin{array}{l}\text { Unadjusted } \\
\text { Men } \\
\text { OR }(95 \% \mathrm{Cl})\end{array}$ & $\begin{array}{c}\text { Adjusted } \\
\text { Men } \\
\text { OR }(95 \% \mathrm{Cl})\end{array}$ & $\begin{array}{c}\text { Overall } \\
\text { adjusted } \\
\text { OR }(95 \% \mathrm{CI})\end{array}$ \\
\hline Acetaminophen & $\begin{array}{c}1.0 \\
\text { (reference) }\end{array}$ & $\begin{array}{c}1.0 \\
\text { (reference) }\end{array}$ & $\begin{array}{c}1.0 \\
\text { (reference) }\end{array}$ & $\begin{array}{c}1.0 \\
\text { (reference) }\end{array}$ & $\begin{array}{c}1.0 \\
\text { (reference) }\end{array}$ \\
\hline Acetaminophen + aspirin + caffeine & $\begin{array}{c}1.05 \\
(0.76-1.46)\end{array}$ & $\begin{array}{c}0.85 \\
(0.60-1.21)\end{array}$ & $\begin{array}{c}1.18 \\
(0.62-2.25)\end{array}$ & $\begin{array}{c}0.94 \\
(0.46-1.89)\end{array}$ & $\begin{array}{c}0.87 \\
(0.64-1.19)\end{array}$ \\
\hline Non-steroidal medications & $\begin{array}{c}0.88 \\
(0.62-1.26)\end{array}$ & $\begin{array}{c}0.97 \\
(0.67-1.42)\end{array}$ & $\begin{array}{c}0.73 \\
(0.38-1.41)\end{array}$ & $\begin{array}{c}0.93 \\
(0.46-1.89)\end{array}$ & $\begin{array}{c}0.97 \\
(0.69-1.34)\end{array}$ \\
\hline Other over-the- counter & $\begin{array}{c}0.81 \\
(0.35-1.87)\end{array}$ & $\begin{array}{c}0.94 \\
(0.40-2.21)\end{array}$ & $\begin{array}{c}1.84 \\
(0.55-6.19)\end{array}$ & $\begin{array}{c}1.02 \\
(0.26-4.04)\end{array}$ & $\begin{array}{c}1.02 \\
(0.50-2.06)\end{array}$ \\
\hline Prescribed meds + NSAIDs & $\begin{array}{c}0.88 \\
(0.62-1.26)\end{array}$ & $\begin{array}{c}0.97 \\
(0.67-1.41)\end{array}$ & $\begin{array}{c}0.85 \\
(0.46-1.55)\end{array}$ & $\begin{array}{c}0.93 \\
(0.46-1.88)\end{array}$ & $\begin{array}{c}0.96 \\
(0.69-1.34)\end{array}$ \\
\hline Triptans & $\begin{array}{c}1.11 \\
(0.76-1.63)\end{array}$ & $\begin{array}{c}0.93 \\
(0.62-1.40)\end{array}$ & $\begin{array}{c}2.37 \\
(1.20-4.71)\end{array}$ & $\begin{array}{c}2.11 \\
(0.97-4.63)\end{array}$ & $\begin{array}{c}1.05 \\
(0.73-1.50)\end{array}$ \\
\hline Barbiturate compounds & $\begin{array}{c}2.29 \\
(1.44-3.64)\end{array}$ & $\begin{array}{c}1.97 \\
(1.21-3.23)\end{array}$ & $\begin{array}{c}1.42 \\
(0.43-4.72)\end{array}$ & $\begin{array}{c}1.29 \\
(0.38-4.37)\end{array}$ & $\begin{array}{c}1.73 \\
(1.10-2.73)\end{array}$ \\
\hline Opiates & $\begin{array}{c}1.74 \\
(1.15-2.63)\end{array}$ & $\begin{array}{c}1.28 \\
(0.81-1.97)\end{array}$ & $\begin{array}{c}3.48 \\
(1.74-6.96)\end{array}$ & $\begin{array}{c}2.76 \\
(1.20-6.38)\end{array}$ & $\begin{array}{c}1.44 \\
(1.10-2.08)\end{array}$ \\
\hline Isometheptene compounds & $\begin{array}{c}0.94 \\
(0.41-2.16)\end{array}$ & $\begin{array}{c}0.85 \\
(0.36-2.02)\end{array}$ & $\begin{array}{c}1.64 \\
(0.38-7.09)\end{array}$ & $\begin{array}{c}1.60 \\
(0.34-7.54)\end{array}$ & $\begin{array}{c}0.93 \\
(0.44-1.98)\end{array}$ \\
\hline
\end{tabular}
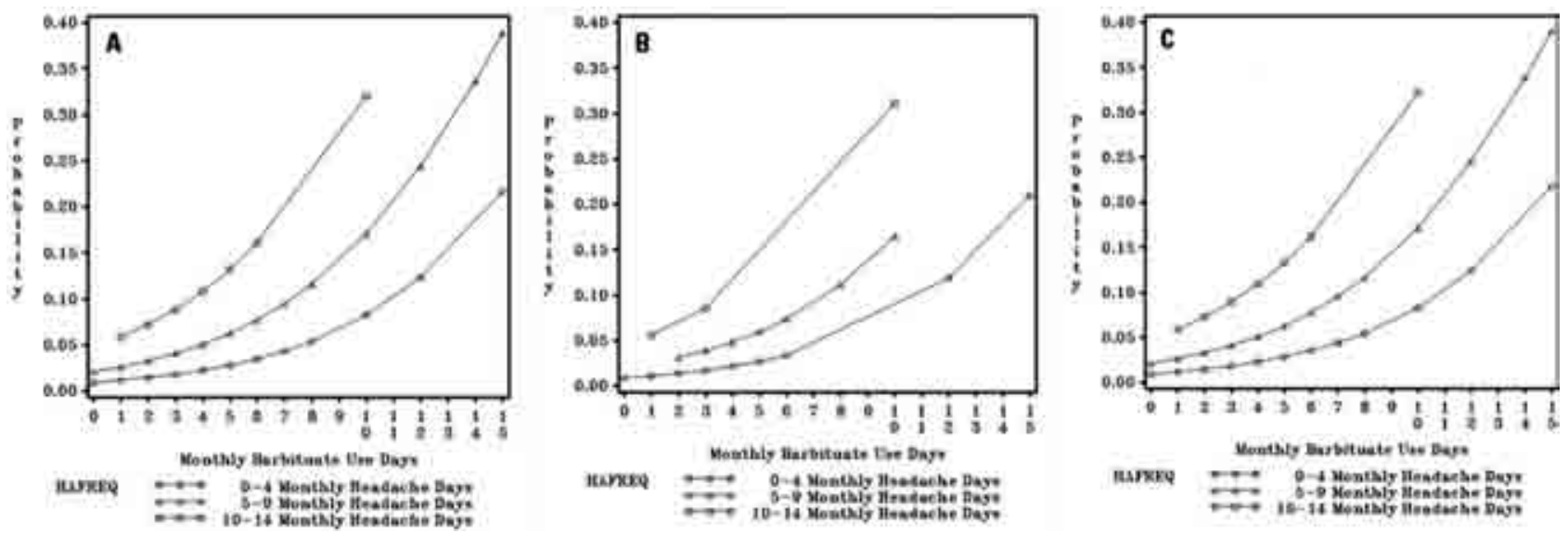

Figure. Probability of developing chronic migraine in 2006 as a function of headache frequency and monthly barbiturate use in 2005 overall $[\mathrm{A}]$, in men $[\mathrm{B}]$ and women $[\mathrm{C}]$. From Bigal et al. ${ }^{35}$ (with permission).

monthly headache frequency was associated with higher probability of development of CM. This effect is illustrated for barbiturates in Figure. Note that increased barbiturate use increases the probability of CM for all headache frequencies, but the magnitude of the effect varies depending on the baseline number of attacks.

Odds of transition to CM increased with elevated monthly barbiturate exposure $(\mathrm{OR}=1.25,95 \% \mathrm{CI}=1.1$ 1.4) controlling for the effects of gender and monthly headache frequency. Similar findings were seen for opiates [- can "opioids" and "opiates" be used interchangeably?? $(\mathrm{OR}=1.44,95 \% \mathrm{CI}=1.1-1.8)$. For opioids, there was a significant main effect of gender and effects were higher in men than in women, although significant in both (OR=2.82, 95\% CI=1.1 -6.90).

Triptans did not increase the risk of $\mathrm{CM}(\mathrm{OR}=1.07$, 95\% CI $=0.89-1.29)$ overall. However, gender effects were seen, and triptans were associated with CM in women with more than 10 days of headache per month at baseline.

Finally, NSAIDs were protective against transition to $\mathrm{CM}$ at low to moderate monthly headache days, but were associated with increased risk of transition to $\mathrm{CM}$ at high levels of monthly headache days. No gender effects were seen for NSAIDs. 


\section{Considerations about the causality of the association}

The framework for assessing the causal link between a specific risk factor and a disease is well established ${ }^{36}$ and discussed herein for the relationship between analgesic use and migraine progression.

The temporal relationship is a first key aspect that needs to be assessed, since exposure always precedes the outcome (excessive medication use precedes $\mathrm{CM}$ ), and this relationship was supported by a clinic-based longitudinal study and a population-based longitudinal study ${ }^{33,35}$. Despite this evidence, we can not exclude the possibility of reverse causation. That is, treatment frequency may be escalated because headaches are worsening.

Accordingly, specificity of findings is of importance. If reverse causation is true, it would happen regard of class of medication and that is not what has been found. Additionally, the strength of association has been well quantified and is different according to classes (opioids and barbiturates $>$ triptans $>$ NSAIDs).

As a third relevant point, studies found a critical dose of exposure and a dose-response relationship that varies per drug ( 5 days for barbiturates, 8 for opioids, 10 for triptans, and only in specific situations for NSAIDs) ${ }^{35}$.

A fourth relevant point regards the consistency of the findings. The association has been replicated in clinicbased and population-based studies using both case control and cohort designs ${ }^{25-27,35}$.

Finally, the alternative hypothesis (medication use increases as a consequence of increased headache frequency) has been considered in the design of the most recent studies ${ }^{37}$. The fact that removing overused medications is followed by headache improvement supports the hypothesis that certain medications may cause $\mathrm{CM}^{9,38}$ However, reverse causality also occurs, as some patients clearly develop increased headache frequency without ever using opioids.

\section{Considerations about the biological plausibility}

Although not unequivocally demonstrated, plausible mechanisms have been proposed and at least partially demonstrated $^{39,40}$. Recent preclinical studies exploring the neuroadaptive changes following sustained exposure to morphine may give some insights into possible causes of why opioids induce migraine progression. Peripherally, exposure to morphine increased expression of calcitonin gene-related peptide (CGRP) in trigeminal primary afferent neurons ${ }^{41}$. CGRP is a neuropeptide involved with pain transmission and with the pathophysiology of migraine. Centrally, they include increased excitatory neurotransmission at the level of the dorsal horn and nucleus caudalis ${ }^{41,42}$. Critically, these neuroadaptive changes persist for long periods of time and the evoked release of CGRP is enhanced following morphine pretreatment. Stimuli known to elicit migraine, such as nitric oxide donors or stress, produce hyperalgesia in morphine- but not in saline-pretreated rats even long after the discontinuation of the opiate. Furthermore, studies have demonstrated increased excitability of the nociceptive pathway in migraine sufferers, and CGRP receptor antagonists have been shown to be efficacious in migraine pain. Thus, such persistent neuroadaptive changes may be relevant to the processes that promote medication overuse headache $(\mathrm{MOH})^{41}$.

Clinical studies support the preclinical findings as well. In humans, exposure to opioids is associated with hyperalgesia, cutaneous allodynia and with the development of a "pain memory state," when sufferers become refractory to other forms of therapy ${ }^{43-46}$.

Neuroimaging studies offer an important opportunity to elucidate the mechanisms of medication-induced headache. In a study measuring glucose metabolism with 18-FDG PET, Fuwal et al. compared individuals with CM and analgesic overuse before and 3 weeks after medication withdrawal and compared the data with those of a control population. Before withdrawal, the bilateral thalamus, orbitofrontal cortex (OFC), anterior cingulate gyrus, insula/ventral striatum and right inferior parietal lobule were hypometabolic, while the cerebellar vermis was hypermetabolic. All dysmetabolic areas recovered to almost normal glucose uptake after withdrawal of analgesics, except the OFC where a further metabolic decrease was found. They concluded that medication overuse headache is thus associated with reversible metabolic changes in pain processing structures like other chronic pain disorders, but also with persistent orbitofrontal hypofunction $^{47}$.

For other medications, such as the triptans, the plausibility is sustained on fewer studies. It is well known that triptans induce transient cutaneous allodynia in humans ${ }^{48}$, and that allodynia is an important risk factor for $\mathrm{CM}^{44,49}$. In animals, sustained or repeated administration of triptans to rats also elicited time-dependent and reversible cutaneous tactile allodynia that was maintained throughout and transiently after drug delivery ${ }^{50}$. Triptan administration increased labeling for CGRP in identified trigeminal dural afferents that persisted long after discontinuation of triptan exposure ${ }^{50}$, suggesting that overuse of these medications could induce neural adaptations that result in a state of latent sensitization, which might increase increased propensity for the development of CM.

\section{Lessons from therapy}

As mentioned before, data suggest a diathesis stress model for $\mathrm{CDH}$. When the diathesis, migraine, 
is combined with the stress, pattern of medication use, CDH may develop. Accordingly, based on the model, removing the stress $(\mathrm{MOH})$ should be associated with improvement of the disease (migraine). In other words, the condition can be altered (prevented or ameliorated) by an appropriate experimental regimen. This has been extensively demonstrated. Detoxification is indeed associated with an increased chance of TM/CM remission ${ }^{7,9,10,51,52}$.

Although high quality clinical trials testing the benefits of medication withdrawal are yet to be conducted, the findings are not only plausible, but also supported by neuroimaging studies. Functional magnetic resonance imaging (fMRI) may indeed be a useful technique for obtaining information on particular neuronal changes in the pain network involved in this condition. In a study where fMRI was conducted before and after medication withdrawal, it was found that before withdrawal, the right supramarginal gyrus, the right inferior and superior parietal cortex were hypoactive. Activity recovered to almost normal 6 months after withdrawal of the offending medications. Data suggest that $\mathrm{MOH}$ is associated with a modification of the pain network, and that these changes are reversible with therapy ${ }^{53}$.

As a final comment, if excessive use of medication induces the appearance of CM, and withdrawal is associated with improvement, recidivism of exposure should be associated with increased risk for developing CM once more. In this regard, Sances et al studied 215 patients consecutively admitted to a headache center for an inpatient detoxification treatment. One year after withdrawal, they were able to re-interview 172 patients (80\%): 38 of these patients (22\%) had relapsed into overuse and 134 (78\%) had not. Factors associated with relapse were intake of more than 30 doses/ month ( $\mathrm{P}=0.004)$, smoking $(\mathrm{P}=0.012)$, alcohol consumption $(\mathrm{P}=0.037)$, non-confirmation of $\mathrm{MOH}$ diagnosis 2 months after detoxification $(\mathrm{P}=0.000)$, and return to overused $\operatorname{drug}(\mathrm{s})(\mathrm{P}=0.000)$. Recidivism was associated with redevelopment of $\mathrm{CDH}^{54}$.

\section{REFERENCES}

1. Bigal ME, Lipton RB. The prognosis of migraine. Curr Opin Neurol 2008;21: 301-308.

2. Bigal ME, Lipton RB. Clinical course in migraine: conceptualizing migraine transformation. Neurology 2008;71:848-855.

3. Boes CJ, Black DF, Dodick DW. Pathophysiology and management of transformed migraine and medication overuse headache. Semin Neurol 2006; 26:232-241.

4. Mathew NT, Reuveni U, Perez F. Transformed or evolutive migraine. Headache 1987;27:102-106.

5. Mathew NT. Transformed migraine. Cephalalgia 1993;13(Suppl 12):S78-S83.

6. Scher Al, Stewart WF, Ricci JA, Lipton RB. Factors associated with the onset and remission of chronic daily headache in a population-based study. Pain 2003;106:81-89.

7. Mathew NT. Transformed migraine, analgesic rebound, and other chronic daily headaches. Neurol Clin 1997;15:167-186.
8. Goadsby PJ. Is medication-overuse headache a distinct biological entity? Nat Clin Pract Neurol 2006:2:401.

9. Zeeberg P, Olesen J, Jensen R. Discontinuation of medication overuse in headache patients: recovery of therapeutic responsiveness. Cephalalgia 2006;26:1192-1198.

10. Bigal ME, Rapoport AM, Sheftell FD, Tepper SJ, Lipton RB. Transformed migraine and medication overuse in a tertiary headache centre: clinical characteristics and treatment outcomes. Cephalalgia 2004;24:483-490.

11. Ballantyne JC, Mao J. Opioid therapy for chronic pain. N Engl J Med 2003; 349:1943-1953.

12. Sullivan LE, Chawarski M, O'Connor PG, Schottenfeld RS, Fiellin DA. The practice of office-based buprenorphine treatment of opioid dependence: is it associated with new patients entering into treatment? Drug Alcohol Depend 2005;79:113-116.

13. Caudill-Slosberg MA, Schwartz LM, Woloshin S. Office visits and analgesic prescriptions for musculoskeletal pain in US: 1980 vs. 2000. Pain 2004;109: 514-519.

14. Silberstein SD. Practice parameter: evidence-based guidelines for migraine headache (an evidence-based review): report of the Quality Standards Subcommittee of the American Academy of Neurology. Neurology 2000;55:754-762.

15. Fontanillas N, Colas R, Munoz P, Oterino A, Pascual J. Long-term evolution of chronic daily headache with medication overuse in the general population. Headache 2010;50:981-988.

16. Dodick DW. Debate: analgesic overuse is a cause, not consequence, of chronic daily headache. Analgesic overuse is not a cause of chronic daily headache. Headache 2002;42:547-554.

17. Tepper SJ, Tepper DE. Breaking the cycle of medication overuse headache. Cleve Clin J Med 2010;77:236-242.

18. Lipton RB, Bigal ME, Steiner TJ, Silberstein SD, Olesen J. Classification of primary headaches. Neurology 2004;63:427-435.

19. Silberstein SD, Olesen J, Bousser MG. The International Classification of Headache Disorders, 2nd Edition (ICHD-II)-revision of criteria for 8.2 Medication-overuse headache. Cephalalgia 2005;25:460-465.

20. Olesen J, Bousser MG, Diener HC, et al. New appendix criteria open for a broader concept of chronic migraine. Cephalalgia 2006;26:742-746.

21. Silberstein SD, Lipton RB, Sliwinski M. Classification of daily and near-daily headaches: field trial of revised IHS criteria. Neurology 1996;47:871-875.

22. Classification Committee of the International Headache Society. Classification and diagnostic criteria for headache disorders, cranial neuralgias and facial pain. Cephalalgia 1988.

23. Classification Committee of the International Headache Society. The International Classification of Headache Disorders. 2nd Edition. Cephalalgia 2004;24(Suppl 1):S1-S149.

24. Bigal M, Rapoport A, Sheftell F, Tepper S, Lipton R. The International Classification of Headache Disorders revised criteria for chronic migrainefield testing in a headache specialty clinic. Cephalalgia 2007;27:230-234.

25. Katsarava Z, Schneeweiss S, Kurth $T$, et al. Incidence and predictors for chronicity of headache in patients with episodic migraine. Neurology 2004;62:788-790.

26. Wilkinson SM, Becker WJ, Heine JA. Opiate use to control bowel motility may induce chronic daily headache in patients with migraine. Headache 2001;41:303-309.

27. Bahra A, Walsh M, Menon S, Goadsby PJ. Does chronic daily headache arise de novo in association with regular use of analgesics? Headache 2003; 43:179-190.

28. Paemeleire K, Bahra A, Evers S, Matharu MS, Goadsby PJ. Medicationoveruse headache in patients with cluster headache. Neurology 2006;67: 109-113.

29. Williams L, O'Connell K, Tubridy N. Headaches in a rheumatology clinic: when one pain leads to another. Eur J Neurol 2008;15:274-277.

30. Lipton RB, Bigal ME, Diamond M, Freitag F, Reed ML, Stewart WF. Migraine prevalence, disease burden, and the need for preventive therapy. Neurology 2007;68:343-349.

31. Bigal ME, Serrano D, Lipton RB. The acute treatment of episodic and chronic migraine in the United States. Cephalalgia 2009;29:891-897.

32. Scher Al, Stewart WF, Liberman J, Lipton RB. Prevalence of frequent headache in a population sample. Headache 1998;38:497-506.

33. Scher Al, Lipton LR, Stewart WF, Bigal ME. Patterns of medical consultation and medication use by chronic and episodic headache sufferers in the general population: results from the frequent headache epidemiology study. Cephalgia 2010;30:321-328. 
34. Zwart JA, Dyb G, Hagen K, Svebak S, Holmen J. Analgesic use: a predictor of chronic pain and medication overuse headache: the Head-HUNT Study. Neurology 2003;61:160-164.

35. Bigal ME, Serrano D, Buse D, Scher A, Stewart WF, Lipton RB. Acute migraine medications and evolution from episodic to chronic migraine: a longitudinal population-based study. Headache 2008;48:1157-1168.

36. Himsworth H. Bradford Hill and statistics in medicine. Stat Med 1982;1: 301-303.

37. Bigal ME, Lipton RB. Excessive acute migraine medication use and migraine progression. Neurology 2008;71:1821-1828.

38. Bigal ME, Sheftell FD, Tepper SJ, Rapoport AM. Discontinuation of medication overuse in headache patients: recovery of therapeutic responsiveness. Cephalalgia 2007;27:568

39. King T, Ossipov MH, Vanderah TW, Porreca F, Lai J. Is paradoxical pain induced by sustained opioid exposure an underlying mechanism of opioid antinociceptive tolerance? Neurosignals 2005;14:194-205.

40. Yamamoto T, Nair $P$, Vagner J, et al. A structure-activity relationship study and combinatorial synthetic approach of C-terminal modified bifunctional peptides that are delta/mu opioid receptor agonists and neurokinin 1 receptor antagonists. J Med Chem 2008;51:1369-1376.

41. De Felice M, Porreca F. Opiate-induced persistent pronociceptive trigeminal neural adaptations: potential relevance to opiate-induced medication overuse headache. Cephalalgia 2009;29:1277-1284.

42. Edelmayer RM, Vanderah TW, Majuta L, et al. Medullary pain facilitating neurons mediate allodynia in headache-related pain. Ann Neurol 2009;65: 184-193.

43. Perrotta A, Serrao M, Sandrini G, et al. Sensitisation of spinal cord pain processing in medication overuse headache involves supraspinal pain control. Cephalalgia 2010;30:272-284.

44. Bigal ME, Ashina S, Burstein R, et al. Prevalence and characteristics of allodynia in headache sufferers: a population study. Neurology 2008;70: 1525-1533.

45. Jakubowski M, Levy D, Kainz V, Zhang XC, Kosaras B, Burstein R. Sensitization of central trigeminovascular neurons: blockade by intravenous naproxen infusion. Neuroscience 2007;148:573-583.

46. Jakubowski M, Levy D, Goor-Aryeh I, Collins B, Bajwa Z, Burstein R. Terminating migraine with allodynia and ongoing central sensitization using parenteral administration of COX1/COX2 inhibitors. Headache 2005;45:850-861.

47. Fumal A, Laureys S, Di Clemente L, et al. Orbitofrontal cortex involvement in chronic analgesic-overuse headache evolving from episodic migraine. Brain 2006;129:543-550.

48. Burstein R, Collins B, Jakubowski M. Defeating migraine pain with triptans: a race against the development of cutaneous allodynia. Ann Neurol 2004;55:19-26.

49. Lipton RB, Bigal ME, Ashina S, et al. Cutaneous allodynia in the migraine population. Ann Neurol 2008;63:148-158.

50. De Felice M, Ossipov MH, Wang R, et al. Triptan-induced latent sensitization: a possible basis for medication overuse headache. Ann Neurol 2010; 67:325-337.

51. Andrasik F, Grazzi L, Usai S, Kass S, Bussone G. Disability in chronic migraine with medication overuse: treatment effects through 5 years. Cephalalgia 2009;29:13-17.

52. Grazzi L, Andrasik F, Usai S, Bussone G. Treatment of chronic migraine with medication overuse: is drug withdrawal crucial? Neurol Sci 2009;30 (Suppl 1):S85-S88.

53. Grazzi L, Chiapparini L, Ferraro S, et al. Chronic migraine with medication overuse pre-post withdrawal of symptomatic medication: clinical results and FMRI correlations. Headache 2010;50:998-1004.

54. Sances G, Ghiotto N, Galli F, et al. Risk factors in medication-overuse headache: a 1-year follow-up study (care II protocol). Cephalalgia 2009;29:17-32. 